\title{
Remote Sensing Assessment of Paspalum quadrifarium Grasslands in the Flooding Pampa, Argentina
}

\author{
Lorena P. Herrera, ${ }^{1}$ Vanina Gómez Hermida, ${ }^{2}$ Gustavo A. Martinez, ${ }^{3}$ \\ Pedro Laterra, ${ }^{4}$ and Néstor Maceira ${ }^{5}$
}

\begin{abstract}
Authors are ${ }^{1}$ Graduate student, CONICET, Facultad de Ciencias Agrarias, Universidad Nacional de Mar del Plata, EEA Balcarce, INTA, CC 276, 7620 Balcarce, Buenos Aires, Argentina; ${ }^{2}$ Graduate student, EEA San Luis, INTA, CC 17, 5730 Villa Mercedes, San Luis, Argentina; ${ }^{3}$ Professor, Centro de Geología de Costas y Cuaternario, Universidad Nacional de Mar del Plata, CC 722, 7600 Mar del Plata, Buenos Aires, Argentina; ${ }^{4}$ Associate Professor, Facultad de Ciencias Agrarias, Universidad Nacional de Mar del Plata, EEA Balcarce, INTA, CC 276, 7620 Balcarce, Buenos Aires, Argentina; and ${ }^{5}$ Researcher, EEA Balcarce, INTA, CC 276, 7620 Balcarce, Buenos Aires, Argentina.
\end{abstract}

\begin{abstract}
The knowledge of the distribution, area, and current conservation status of relict natural grasslands dominated by the talltussock grass Paspalum quadrifarium Lam. ("pajonal") in the Flooding Pampa (Argentina) is relevant for the identification of conservation sites and sustainable management and land-use planning. Since European settlement, vast areas of pajonal were converted to croplands and short-grass prairies. The only available vegetation map of these grasslands was made in the mid-20th century. We evaluated 2 methods of land-cover classification (supervised and unsupervised) using a Landsat TM satellite image over an area of $2258.21 \mathrm{~km}^{2}$ in Ayacucho county, where pajonal still persists as an important ecosystem. At the paddock scale, this grassland community presents a complex structure in which the pajonal is not a pure category but a mosaic of tall and short grasses. Six categories of land cover were adopted (crops, sown pastures, short grasses, pajonal, wetlands, and urban areas). A very good overall accuracy was obtained for both classifications $(86.9 \%$ and $87.9 \%$ for supervised and unsupervised classifications, respectively). However, both producer's and user's accuracies for the pajonal and short grasses were better for the unsupervised classification than for the supervised classification. The pajonal class occupied only $20 \%$ of the study area with patch size ranging between 0.09 and 1653 ha. This work suggests an important replacement of tall-tussock grass by short-grass matrix, which represents noticeable structural and functional changes. The unsupervised classification of Landsat image seems a particularly suitable method for mapping complex vegetation units like the highly fragmented pajonal of the Flooding Pampa and should be an important tool for management and tracking future changes.
\end{abstract}

\section{Resumen}

Conocer la distribución espacial, extensión y estado de conservación actual de pastizales en estado original dominados por "Tall-tussock grass" (Paspalum quadrifarium Lam.) ("pajonal”) en la Pampa Inundable (Argentina), es relevante para identificar áreas de conservación y planear el manejo sustentable del uso de la tierra de la región. A partir del asentamiento europeo, grandes áreas de "pajonal" fueron convertidas a tierras de cultivos y praderas de pastos cortos. El único mapa de vegetación disponible de la región fue realizado a mediados del siglo 20. En este trabajo, evaluamos 2 métodos de clasificación del uso de la tierra (clasificación supervisada y clasificación no supervisada) para identificar al "pajonal”. Se trabajó con una imagen Landsat TM, correspondiente a un área de $2258.21 \mathrm{~km}^{2}$ en el Partido de Ayacucho, donde todavía persiste el "pajonal" como un importante ecosistema. A la escala del potrero, esta comunidad presenta una estructura compleja, donde el "pajonal" no se presenta como una categoría pura sino como un mosaico de pastos altos y pastos cortos. Seis categorías de cobertura de la tierra fueron adoptadas para las clasificaciones (cultivos, pastos cultivadas, pastos cortos, pajonal, cuerpos de agua, y áreas urbanas). Se obtuvieron grados de certeza global muy buenos para ambas clasificaciones $(86.9 \%$ y $87.9 \%$ para clasificación supervisada y no supervisada, respectivamente). Sin embargo, tanto la certeza del productor como la del usuario para las clases "pajonal" y pastos cortos fueron mejor para la clasificación no supervisada. La clase "pajonal” ocupó solamente el $20 \%$ del área de estudio presentando tamaños promedios de parches de 0.09 y 1653 ha. Este trabajo sugiere un importante reemplazo del "tall tussock grass" por el pastizal corto, lo cual representa destacados cambios funcionales y estructurales. La clasificación no supervisada a partir de la imagen Landsat resulta un método particularmente adecuado para el mapeo de unidades de vegetación complejas como el "pajonal" de la Pampa Inundable y debería ser una importante herramienta para el manejo y monitoreo de cambios futuros en el uso de la tierra de la región.

Key Words: land use, Landsat TM, pajonal, supervised and unsupervised classification

Research was funded by Agencia Nacional de Promoción Científica y Tecnológica (PICT 080 3994), Universidad Nacional de Mar del Plata, and Instituto Nacional de Tecnología Agropecuaria (INTA) (Argentina). Comisión Nacional de Actividades Espaciales (CONAE) supplied the satellite data.

This work is part of the thesis submitted by Lic. Lorena Herrera in fulfillment of the requirement for the "Doctorado en Ciencias Biológicas" of the National University of Mar del Plata (UNMdP).

Correspondence: Lorena P. Herrera, Facultad de Ciencias Agrarias, Universidad Nacional de Mar del Plata, EEA Balcarce, INTA, CC 276, 7620 Balcarce, Buenos Aires, Argentina. Email: Iherrera@mdp.edu.ar

Manuscript received 22 August 2003; manuscript accepted 23 January 2005 


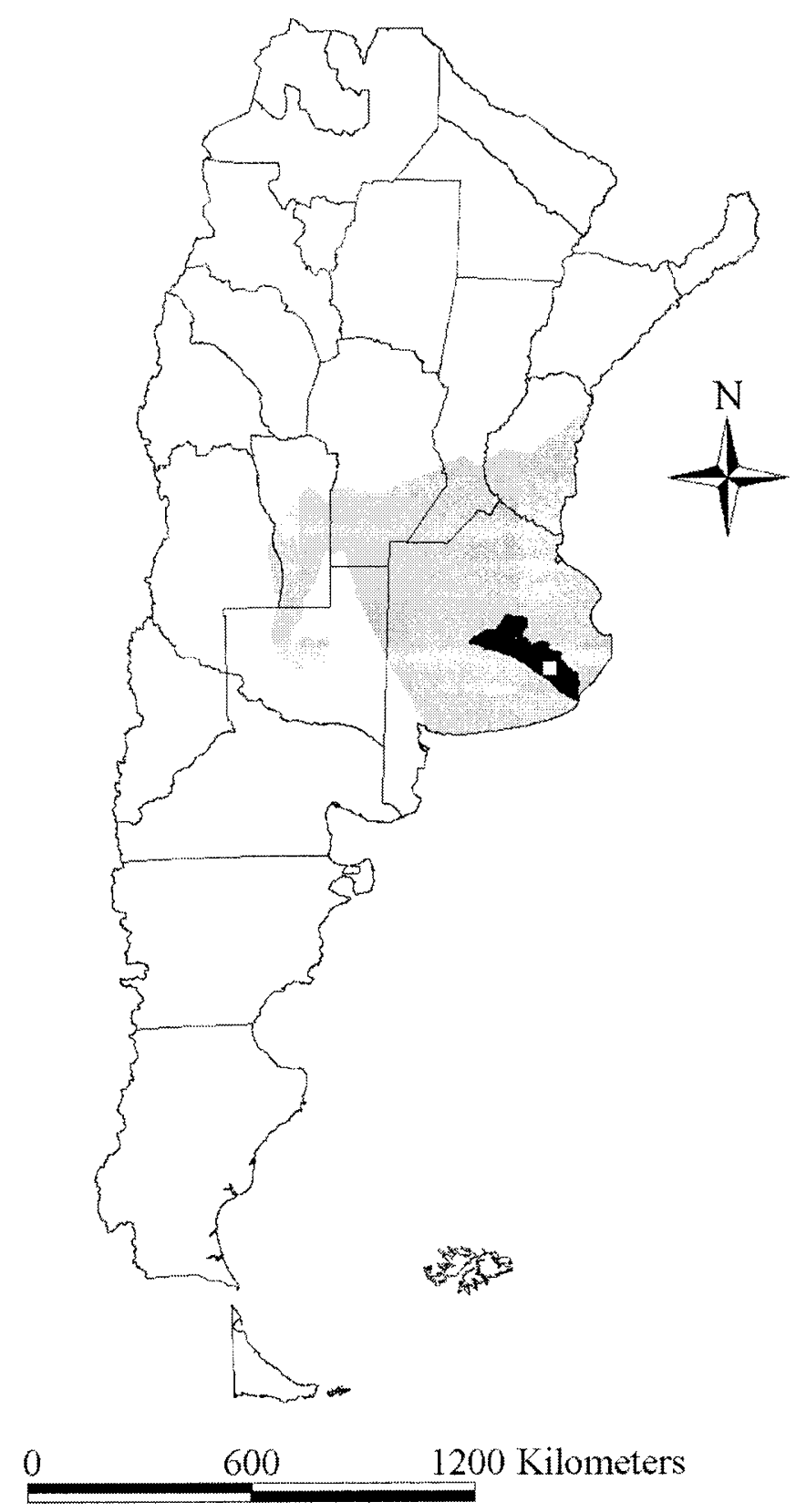

Figure 1. Location of the study area in the Pampa region, Argentina (grey area). Black area represents the Paspaletum landscape according to Vervoorst (1967).

\section{INTRODUCTION}

Paspalum quadrifarium Lam. (paja colorada) is a South American C-4 tussock grass, which extends between $30^{\circ}$ and $39^{\circ} \mathrm{S}$ Lat, forming dense and tall-tussock grasslands, locally known as "pajonal of paja colorada" (hereafter, pajonal) (Vervoorst 1967; Quarin and Lombardo 1986). Significant transformation and loss of this and other types of pristine vegetation has occurred since European settlement, mainly as a result of human activity. In the Pampa region of Argentina, pajonal grasslands probably dominated the original vegetation over vast areas before agricultural soils were turned into cropland (Laterra et al. 1998, 2003). Approximately 50 years ago, the pajonal was described as the dominant plant community over a wide fringe of $14000 \mathrm{~km}^{2}$, extending from NW to SE in the middle-south of the Flooding Pampa subregion ("Paspaletum" sensu Vervoorst 1967, Fig. 1). Today, natural and seminatural grasslands primarily exist in areas of the Pampa that are periodically flooded (Soriano 1991).

Current management of the pajonal remnants is based on periodic or occasional burnings that induce short-term enhancement in quality, accessibility, and productivity and on transitional floristic stages, characterized by different types of forage (Laterra 1997; Juan et al. 2000) and weed species (Cauhépé 1990; Laterra et al. 1998, 2003). Other disturbances, such as plowing or herbicide application, are being used to reduce the pajonal remnants and replace them with short grasses or annual crops. Although some of the transitional stages mentioned above are reversible, the short grassland does not seem to be returning (Laterra et al. 1998). Therefore, the extent of the pajonal has diminished during the past decades. The magnitude, rate, and spatial pattern of pajonal reduction have not been scientifically evaluated. Quantification of pajonal reduction is important because of the role it plays in the conservation of autochthonous biodiversity (Comparatore et al. 1996) and the maintenance of critical ecosystem processes (Perelman et al. 2003).

Satellite imagery has been useful for analyzing and mapping vegetation over large areas (Tucker et al. 1985; Tueller 1989). Digital image classification is an important tool for evaluating ecosystem function and change over large areas. Image classification methods can be broadly grouped into 2 major categories. The first is called supervised classification (SC), which requires considerable knowledge of the area to identify areas known to belong to different categories. Statistics describing training areas for each category are generated by the image processing software (mean and standard deviation). Remaining unknown areas, often are classified into a statistically unique category (Tueller 1989). The second major approach to image classification is called unsupervised classification (USC), where the analysis identifies statistically unique categories of stuff (based on user provided parameters) and then assigns remaining image pixels to each category. Categories developed using this procedure are usually of unknown composition and can result in a high degree of statistical overlay (the same stuff differentiated into 2 or more categories or different stuff that cannot be statistically discriminated). This intermediate step must be followed by cluster interpretation, where the user assigns physical attributes (e.g., woodland, grassland, urban) to each category and reconciles classification problems. The USC procedure is relatively easy to modify and can be run under a variety of user-defined parameters until a satisfactory classification is reached (Tueller 1989).

Both supervised and unsupervised classifications seem to have considerable potential for the discrimination and management of grasslands communities (Tueller 1989; Guo et al. 2000). Many authors have pointed out the difficulty in discriminating grasslands with similar spectral properties (Egbert et al. 1997; Price et al. 1999). However, these limitations or difficulties can be accounted for and in some cases corrected. Image classification is imperfect, however, it still provides the ability to evaluate large areas that would be impossible to evaluate using any other method (Everitt et al. 1981). 
Classification studies of vegetation in the Flooding Pampa using remote sensing data to discriminate similar vegetation types are scarce. Guerschman et al. (2003) explored the use of multitemporal Landsat Thematic Mapper (TM) data for the classification of land cover types in the southwestern portion of the Argentina Pampas, including a portion of the Flooding Pampa. Other researchers have focused on the analysis of functional heterogeneity (Paruelo et al. 2001) and the estimation of pasture productivity (Chanetón et al. 1995; Paruelo et al. 1998, 1999) at a regional scale, using the Normalized Difference Vegetation Index (NDVI) data observed by Advanced Very High Resolution Radiometer (AVHRR) satellites. Landsat TM and Enhanced Thematic Mapper (ETM) images were just recently used for classification studies of vegetation cover in the West Pampa (Demaria et al. 2004).

This work is the first contribution to the description and mapping of pajonal grasslands of the Flooding Pampa using remote sensing data. The main goals were: 1) to assess the spectral properties of pajonal remnants and replacement vegetation, 2) to compare the feasibility of supervised and unsupervised classifications to discriminate the pajonal from other grassland communities, and 3) to generate a preliminary vegetation map of a $2258.21 \mathrm{~km}^{2}$ area in the Ayacucho county, where pajonal still persists as an important component of the vegetation. Ecologically, this research will be used to develop a baseline assessment of the various vegetation components.

\section{METHODOLOGY}

\section{Study Area}

The study area was a $2258.21 \mathrm{~km}^{2}$ area in the Ayacucho county, Province of Buenos Aires. The area (lat $37^{\circ} 05^{\prime}$ to $37^{\circ} 31^{\prime} \mathrm{S}$; long $58^{\circ} 13^{\prime}$ to $\left.58^{\circ} 44^{\prime} \mathrm{W}\right)$, which includes the Flooding Pampa of Argentina (Soriano 1991), was originally classified as pajonal by Vervoorst (1967) (Fig. 1). It is a very flat area covered with Aeolian silt deposits (loess) of the Cenozoic Age (Frenguelli 1950), with halomorphic and hydromorphic soils that are periodically affected by floods. Natural or seminatural grasslands devoted to cattle grazing cover most of this region. The region is humid and temperate with a mean annual precipitation of $1000 \mathrm{~mm}$. The mean annual temperature is $14^{\circ} \mathrm{C}$ with a mean minimum temperature of $6.8^{\circ} \mathrm{C}$ in July and a mean maximum of temperature of $21.8^{\circ} \mathrm{C}$ in January (Soriano et al. 1991).

At the paddock scale, the pajonal presents a mosaic structure of 2 types: tall and dense patchy stands dominated by P. quadrifarium (TG) and various other community types dominated by short grasses (SG) extensively described by Burkart et al. (1990), Perelman et al. (2001), and Perelman et al. (2003). These 2 community types present an important physiognomic contrast, especially during winter when TG presents a 100 to $150-\mathrm{cm}$-high canopy composed mainly of standing dead biomass (Laterra et al. 2003), whereas SG canopy (no more than $50-70 \mathrm{~cm}$ in height) is composed of diverse plant communities with both warm- and cold-season species.

TG and SG were found in different proportions throughout the study area. These areas were subsequently divided (a priori) into 3 structural categories based on relative cover: open pajonal (TG occupying up to $25 \%$ of the paddock area), semiopen pajonal (TG occupying $25 \%-50 \%$ of the paddock area), and dense pajonal (TG occupying more than $50 \%$ of the paddock area).

\section{Satellite Image Information}

A Landsat 5 TM satellite image was acquired on 26 August 1998 and used in this study. During this period the TG phase presents a maximum percent of standing dead tissue, and its spectral signature can be distinguished from the spectral signature of other cover types. Previous analysis of the summer and winter images allowed for the comparison of the spectral response between TG and SG. The spectral contrast between the TG and SG community types was maximized during winter. The TG community type was also more easily separable from other landscape types. The TM image was geometrically registered (first-order polynomial) using ground control points from topographic maps in Erdas Imagine 8.3.1 (Mather 1999). Well-defined features in the image, such as road intersections, corners of paddocks, bends in the rivers, roads, and boundaries of cities, were chosen as ground control points. The image base used was the Traverse Mercator Projection (Gauss Krugger) with an International Ellipsoid (1909). The root mean square (RMS) error of the registration process was approximately 1.35 pixels, which was more than adequate for this type of analysis.

\section{Ground Information}

A total of 165 ground points were visited across the region in 1997, 2001, and 2002. These training/verification sites were located using a global positioning system (GPS) and located primarily at easy access points (principal routes and internal roads) within the study area. Logistical and economic considerations did not permit acquiring ground samples randomly throughout the area. However, the large number of sites visited and their dispersal throughout the study area should have minimized any potential sampling biases. Ground sites were selected within relatively homogeneous landscape units greater than 1 ha in area. Sites were characterized as crops, sown pastures, short grasses, pajonal, wetlands, and urban areas (Table 1).

The 165 field sites were split up into 2 groups: 58 training sites (used to optimize classification parameters) and 107 control points (used to assess the accuracy of the final classification). Training sites represented $22.18 \%$ of the image (500.96 ha). Community types that could not be spectrally separated using data from the 58 training sites were combined into a single category when possible. The 107 validation points occurred in the following classes: 18 crops, 4 sown pasture, 33 short grasses, 35 pajonal, 11 wetland, and 6 urban areas.

With the exception of urban development and cultivation, change across the area occurs slowly. Therefore, it is reasonable to assume that ground conditions at the time the sites were visited (1997, 2001, and 2002) should not have changed substantially from site conditions existing when the satellite image was acquired (1998). Furthermore, the primary focus of this study, quantification of extinction-prone pajonal vegetation (Laterra et al. 1998), was conducted closest to the image acquisition date. 
Table 1. Description of land cover classes used for supervised and unsupervised classifications.

\begin{tabular}{ll}
\hline Category & \multicolumn{1}{c}{ Description } \\
\hline Crops & $\begin{array}{c}\text { Annuals crops. such as wheat and oats; main winter } \\
\text { crops sown from mid-June to late August (winter) } \\
\text { and harvested in late December or early January } \\
\text { (early summer). } \\
\text { Pastures are generally part of the crop-rotation } \\
\text { system. They are used during } 3 \text { to } 6 \text { years, and } \\
\text { then the paddock is used for annual crops again. } \\
\text { Where soil conditions are not appropriate for } \\
\text { cropping, it is frequent that native grasslands are } \\
\text { intersowed with Agropyron sp. or } \\
\text { Festuca arundinacea. } \\
\text { Natural grassland used for grazing that was never } \\
\text { ploughed, or successional stages from old crops } \\
\text { or old pastures with a very low cover of the sowed } \\
\text { sown forage species. Species usually found are } \\
\text { short grasses of the genus Stipa, Piptochaetium, } \\
\text { Melica, Paspalum, Poa, Bothriochloa, and } \\
\text { Sporobolus and dicots of the genus Mentha } \\
\text { and Carduus. } \\
\text { Grassland stands partially or completely dominated } \\
\text { by Paspalum quadrifarium; generally describing } \\
\text { a 2-phased mosaic of P. quadrifarium patches } \\
\text { over short-grass matrix. } \\
\text { Clean or turbid bodies of water. } \\
\text { Towns, paved roads, farmhouses, and small patches } \\
\text { of planted trees. }\end{array}$ \\
Prban areas & \\
\hline &
\end{tabular}

\section{Supervised and Unsupervised Classifications}

The SC and USC were performed with Erdas Image 8.3.1 using the following 6 Landsat bands: TM1, TM2, TM3, TM4, TM5, and TM7. For SC, the maximum likelihood algorithm was used, and the spectral signature for each land cover class was defined by the mean pixel response and standard deviation for each band within each training area. The USC was accomplished using the chain algorithm or ISODATA with 100 clusters, which were then manually combined into the 6 land use categories already mentioned. Classification results were subsequently filtered using a $3 \times 3$ median filter to remove the "salt and pepper" effect of the classification.

\section{Accuracy Assessment}

In general, 2 methods were used for the accuracy assessment: the error matrix and the Kappa coefficient (also called KHAT or Kappa index of agreement, KIA) (Chuvieco 1990; Congalton 1991). An error matrix is a square array of numbers organized in rows and columns, which express the number of sampling units (i.e., pixels, cluster of pixels, or polygons) assigned to a particular category relative to the actual category. The columns usually represent the reference data whereas the rows indicate the classification generated from the remotely sensed data. Correct classifications will be recorded in the matrix diagonals whereas incorrect classifications will correspond to off-diagonal positions. The overall accuracy is calculated by dividing the number of elements (control points) correctly classified by the total number of control points included in the evaluation process (Congalton 1991, 2001). The error matrix also provided errors of commission (errors of inclusion) and omission (errors of exclusion). The former occurs when an area is included in a category it does not belong to, and the latter occurs when an area is excluded from a category that it does belong to (Congalton 1991).

The Kappa statistic quantifies how well a particular classification performed with respect to the random assignment of pixels to each class. This generally results in lower classification accuracy because the probability that a correct pixel classification occurred randomly is removed. All elements in the classification error matrix (not just the main diagonal), contribute to its calculation (Cohen 1960 in Congalton 1991). The equation for the Kappa index is:

$$
\kappa=\left(N \sum_{i=1}^{r} x_{i i}-\sum_{i=1}^{r}\left[x i_{+} \times x_{+i}\right]\right) /\left(N^{2}-\sum_{i=1}^{r}\left[x_{i+} \times x_{+i}\right]\right)
$$

where $r$ is the number of rows in the error matrix, $x_{i i}$ is the number of observations in row $i$ and column $i, x_{i+}$ are the marginal totals of row $i, x_{+i}$ are the marginal totals of column $i$, and $N$ is the total number of observations. The Kappa coefficient value ranges from -1 to 1 , where the latter indicates complete agreement. Monserud (1990) suggested the following scale for Kappa values: $0.05-0.20$, very poor agreement; $0.20-$ 0.40 , poor agreement; $0.40-0.55$, fair agreement; $0.55-0.70$, good agreement; $0.70-0.85$, very good agreement; $0.85-0.99$, excellent agreement; and 0.99-1.00 perfect agreement (values can also be expressed as percentages).

A variant of the Kappa index (conditional Kappa coefficient of agreement, $\kappa_{\mathrm{i}}$ ) (Rosenfield and Fitzpatrick-Lins 1986) was also employed to calculate a measure of agreement for each class. The conditional Kappa for user's class $i$ is calculated as:

$$
\kappa_{i}=\left(N \times x_{i i}\right)-\left(x_{i+} \times x_{+i}\right) /\left(N \times x_{i+}\right)-\left(x_{i+} \times x_{+i}\right)
$$

where $\kappa_{i}$ is the conditional Kappa coefficient of agreement for the $i$ th category, $N$ is the total number of observations, $x_{i i}$ is the number of correct observations for the $i$ th category, $x_{i+}$ is the $i$ th row marginal, and $x_{+i}$ is the $i$ th column marginal.

The accuracies of the SC and USC were assessed using the 107 control points previously mentioned. Each control point was established 5 pixels $(150 \mathrm{~m})$ from the edge of the route or road to eliminate edge effects. The point was defined by a set of $3 \times 3$ pixels around the control point. The cover class that best represented the vegetation within the $8100 \mathrm{~m}^{2}(3 \times 3$ pixel set) area was chosen for each point. The exception was the intrinsically heterogeneous pajonal class where the occurrence of the class in only one pixel $\left(900 \mathrm{~m}^{2}\right)$ resulted in the point being classified as pajonal.

\section{Comparison Between Supervised and Unsupervised Classifications}

A contingency table between cover classes assigned to control points was constructed for calculation of the Cramer's $V$ correlation coefficient. This coefficient was used as a measure of association between both classified images. The Cramer's $V$ 
Table 2. Error matrix for the supervised classification. The diagonal contains correctly classified reference sites. All off-diagonal records are classification errors. Errors along the horizontal are commission errors (error of inclusion), and errors along the vertical are omission errors (error of exclusion).

\begin{tabular}{|c|c|c|c|c|c|c|c|c|}
\hline \multirow[b]{2}{*}{ Classified data } & \multicolumn{8}{|c|}{ Reference data } \\
\hline & C & SP & $S G$ & $P$ & W & UA & Total & $\begin{array}{l}\text { \%User's } \\
\text { accuracy }\end{array}$ \\
\hline Crops $(C)$ & 18 & & & 1 & & & 19 & 94.7 \\
\hline Sown pastures (SP) & & 4 & & & & & 4 & 100.0 \\
\hline Short grasses (SG) & & & 26 & 6 & & & 33 & 81.3 \\
\hline Pajonal (P) & & & 7 & 28 & & & 35 & 80.0 \\
\hline Wetlands (W) & & & & & 11 & & 11 & 100.0 \\
\hline Urban areas $(\mathrm{UA})$ & & & & & & 6 & 6 & 100.0 \\
\hline Total & 18 & 4 & 33 & 35 & 11 & 6 & $n=107$ & \\
\hline \multicolumn{9}{|l|}{ \%Producer's } \\
\hline accuracy & 100.0 & 100.0 & 78.8 & 80.0 & 100.0 & 100.0 & & \\
\hline \multicolumn{9}{|c|}{ Overall accuracy: 93/107 $=86.9 \%$} \\
\hline
\end{tabular}

coefficient ranged from 0 , indicating no correlation, to 1 , indicating perfect correlation. The chi-square statistic (Zar 1984) was used to test Cramer's V correlation coefficients. The Kappa statistic was also calculated as a measure of agreement between the 2 images.

\section{RESULTS AND DISCUSSION}

\section{Classification Methods}

The resulting error matrices for SC and USC are presented in Tables 2 and 3, respectively. A very good overall accuracy was obtained for both classification methods. The overall accuracy of the final map for SC was $86.9 \%$ (Kappa $=82.7 \%$ ); and $87.9 \%$ for USC (Kappa $=83.8 \%$ ). For individual classes, 2 accuracies were calculated: producer's accuracy, which indicates the percentage of time a vegetation class identified on the ground is classified in the same category on the map, and user's accuracy, which indicates the probability that a pixel classified into a given class actually represents that class on the ground (Congalton 1991). Results for the 2 primary classes (pajonal and short grasses) were similar for the user's and producer's accuracies in both the SC and USC. Short grasses did produce higher user-accuracy levels, however, the difference was marginal. The pajonal class produced higher producer accuracies in the USC, but again the difference was slight. Individual class accuracies were all at or above the $80 \%$ level, meaning both techniques effectively discriminated these land cover types (Monserud 1990). Table 4 compares class accuracies for all classes using both the SC and USC approaches. The low accuracy values for the pajonal class obtained with SC were mainly the result of confusion of the pajonal class with the short-grasses class. Seven of 33 SG control points were classified as pajonal, whereas 6 of 35 pajonal control points were classified as short grasses.

The better performance of the USC for short grasses and pajonal systems was a bit of a surprise, especially given the
Table 3. Error matrix for the unsupervised classification. The diagonal contains correctly classified reference sites. All off-diagonal records are classification errors. Errors along the horizontal are commission errors (error of inclusion), and errors along the vertical are omission errors (error of exclusion).

\begin{tabular}{|c|c|c|c|c|c|c|c|c|}
\hline \multirow[b]{2}{*}{ Classified data } & \multicolumn{8}{|c|}{ Reference data } \\
\hline & C & SP & $S G$ & $P$ & W & UA & Total & $\begin{array}{l}\text { \%User's } \\
\text { accuracy }\end{array}$ \\
\hline Crops $(C)$ & 18 & & & 1 & & & 19 & 94.7 \\
\hline Sown pastures (SP) & & 3 & & & & 1 & 4 & 75.0 \\
\hline Short grasses (SG) & & 1 & 27 & 2 & & 1 & 31 & 87.1 \\
\hline Pajonal (P) & & & 5 & 32 & & & 37 & 86.5 \\
\hline Wetlands (W) & & & 1 & & 11 & 1 & 13 & 84.6 \\
\hline Urban areas (UA) & & & & & & 3 & 3 & 100.0 \\
\hline Total & 18 & 4 & 33 & 35 & 11 & 6 & $n=107$ & \\
\hline \multicolumn{9}{|l|}{ \%Producer's } \\
\hline accuracy & 100.0 & 75.0 & 81.8 & 91.4 & 100.0 & 50.0 & & \\
\hline \multicolumn{9}{|c|}{ Overall accuracy: 94/107 = $87.9 \%$} \\
\hline
\end{tabular}

better performance of the SC in the other classes. In retrospect, the results should have been expected. All other categories were easily delineated by the interpreter because of their unique physical structure. The ease of identification, combined with the higher level of spectral homogeneity in these altered systems (crops, pastures, wetlands, and urban areas) resulted in the production of fairly clean supervised training classes that did a good job in identifying these classes across the entire area. However, the native pajonal and grassland communities were much more spatially complex, (i.e., mosaic of pajonal, tall grasses, and short grasses). Therefore, it was difficult for the interpreter to obtain a clean training signature for each class, which resulted in poorer performance of the $\mathrm{SC}$ for these classes (Fig. 2). This same trend was obtained for the USC, however, the spectral training classes obtained by the procedure's pixelselection routine produced cleaner training classes for pajonal and short-grass systems than that obtained by SC. Classification accuracy reductions for wetlands and the altered systems were probably more a function of the low ratio of altered to native classes represented within the entire scene (e.g., the probability of obtaining a sample with the proper pixel mix was low).

Overall, both classification methods produced acceptable results. Evaluation of the SC and USC results indicated

Table 4. Conditional Kappa $\left(\kappa_{i}\right)$ for each category used in supervised (SC) and unsupervised (USC) classifications.

\begin{tabular}{lrr}
\hline & \multicolumn{2}{c}{$\kappa_{i}(\%)$} \\
\cline { 2 - 3 } Category & \multicolumn{1}{c}{$\mathrm{SC}$} & USC \\
\hline Crops & 93.7 & 93.7 \\
Sown pastures & 100.0 & 74.0 \\
Short grasses & 69.3 & 81.3 \\
Pajonal & 70.2 & 79.9 \\
Wetlands & 100.0 & 82.7 \\
Urban areas & 100.0 & 100.0 \\
\hline
\end{tabular}




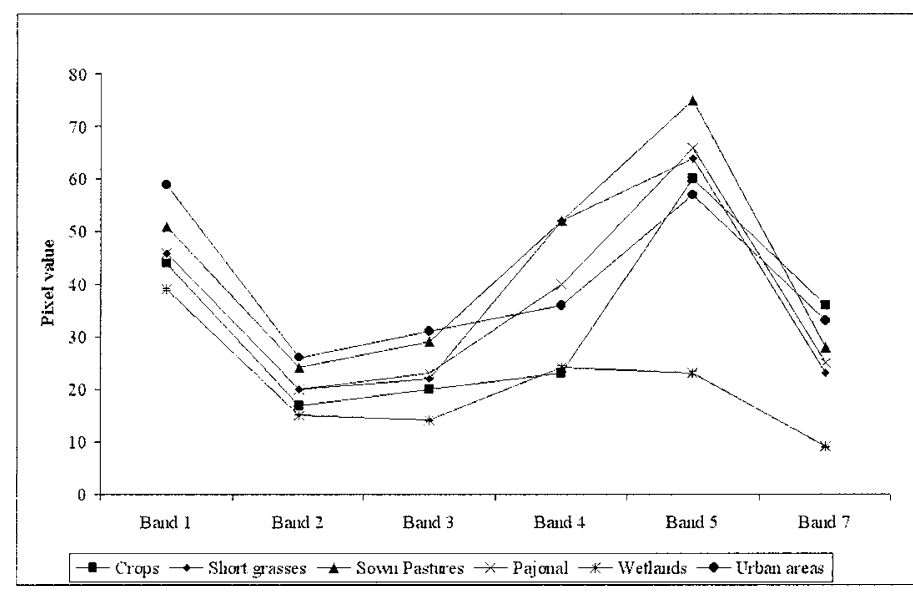

Figure 2. Spectral signatures of land cover classes used in the present work.

a significant agreement between the 2 methods (Cramer's $V=0.57$; chi square $=4092402 ; \mathrm{df}=25 ; P<0.01)$. The Kappa value of $57.9 \%$ also indicated a good agreement between both maps (Monserud 1990). Therefore, either approach can provide essential information needed to assess and manage pajonal systems.

\section{Ecological Considerations}

The pajonal class occupied only $20 \%$ of the study area (Table $5)$. Pajonal remnants resulted in a highly fragmented landscape with patch sizes ranging between 0.09 and 1653 ha. By comparing these results with former descriptions of the region (e.g., Darwin 1839; Vervoorst 1967), it follows that a drastic reduction in the area occupied by the pajonal community has occurred between presettlement times and the present. In contrast with other regions of the Pampas where native grasslands where completely replaced by croplands (Soriano 1991), pajonal replacement in our study area is better explained by the expansion of the short-grass matrix. This is also the case for the entire Paspaletum region where croplands are restricted to scattered paleodunes (Martinez et al. 2001), and pajonal remnants are mostly associated to nonarable soils (L. P. Herrera, G. A. Martínez, V. Gómez Hermida, P. Laterra, and N. Maceira, personal communication, March 2002).

This work has identified an important shift between 2 stable states (tall tussock and short grasses) that represent ecologically and economically significant changes. Such transition cannot be explained by the action of fire or by the action of grazing alone. Successive plowing events are probably a major contribution, and it seems difficult to reverse because of the apparent inefficiency of the dominant species to recolonize sites where fire no longer operates (Laterra et al. 1998; Laterra et al. 2003; Vignolio et al. 2003). Whereas prescribed burning of pajonal stands is able to raise the forage productivity and quality as well as the cattle stocking rates (Laterra 1997; Cauhépé and Laterra 1998; Laterra et al. 2003), it is mostly suitable for continuous pajonal stands. In fragmented landscapes, burnings are interrupted by the short-grass matrix, fire management of the pajonal becomes too time-consuming, and most stockholder efforts are directed to pajonal replacement rather than pajonal management.
Table 5. Percentages of the image window covered by the different land use types resulted from supervised (SC) and unsupervised (USC) classifications.

\begin{tabular}{lcr}
\hline Category & SC & USC \\
\hline Crops & 7.23 & 9.69 \\
Sown pastures & 2.18 & 2.69 \\
Short grasses & 67.04 & 59.40 \\
Pajonal & 18.04 & 21.26 \\
Wetlands & 1.71 & 6.86 \\
Urban areas & 3.80 & 0.09 \\
\hline
\end{tabular}

Because pajonal communities are not represented within protected areas (Krapovickas and Di Giacomo 1998), its progressive replacement is a major concern for the conservation of the Pampas region (Bertonatti and Corcuera 2000). The pajonal structure provides habitat for many species, i.e., several species of birds (Comparatore et al. 1996) and some vegetal species valued as sources of germ plasm (Laterra et al. 2003). Some of these species are associated with pure pajonal stands, whereas others use partially the pajonal patches and the shortgrass patches. Therefore, an optimal arrangement for conservation purposes would be a mosaic including the different communities of the pajonal landscape.

\section{MANAGEMENT IMPLICATIONS}

Classification results using the developed procedures did provide accurate methods for assessing and establishing a baseline for the different vegetation classes of concern. Both supervised and unsupervised classification produced similar results, however, unsupervised classification was better for discriminating short grass and pajonal areas. Other sources of information (e.g., multitemporal Landsat data, radar imagery, and the use of vegetation indexes) might improve classification accuracy and possibly provide additional information about primary production, forage availability through the year, forage quality, and biodiversity conservation.

Although we have no information on the loss rate of pajonal communities, the $20 \%$ of remnant stands found in the study area suggests the importance of developing effective conservation policies. Further work (on a more detailed scale) will allow for better assessment of anthropogenic disturbances. Complementary studies at the regional level must now be undertaken to evaluate the current status of this autochthonous grassland ecosystem and provide the information needed to develop sound scientific policies for conservation and sustainable management over the larger and more complex region.

\section{LITERATURE CITED}

Bertonatti, C., and J. Corcuera. 2000. Situación ambiental Argentina 2000. Buenos Aires, Argentina: Fundación Vida Silvestre Argentina. 436 p.

Burkart, S. E., R. J. C. León, and C. P. Movia. 1990. Inventario fitosociológico del pastizal de la Depresión del Salado (Prov. Bs. As.) en un área representativa de sus principales ambientes. Darwiniana 30:27-69. 
Cauhépé, M. A. 1990. Manejo racional de paja colorada. Revista CREA (Argentina) 143:62-69.

Caunépé, M. A., and P. Laterra. 1998. Manejo de pajonales de paja colorada basado en estudios ecológicos. Balcarce, Buenos Aires, Argentina: Boletín Técnico de la EEA Balcarce, Instituto Nacional de Tecnología Agropecuaria (INTA). No. 145.

Chanetón, E., C. Di Bella, R. J. C. León, and R. C. Rebella. 1995. Análisis regional de la variabilidad espacial y temporal de la productividad primaria de los pastizales de la Pampa Deprimida. Proceedings of the 17th Reunión Argentina de Ecología; April 24-28, 1995; Mar del Plata, Argentina.

Chuvieco, E. 1990. Fundamentos de teledetección espacial. Madrid, España: Rialp, S.A. 453 p.

CoHen, J. 1960. A coefficient of agreement for nominal scales. Educational and Psychological Measurement 20:37-46.

Comparatore, V. M., M. M. Martínez, A. I. Vasallo, M. Barg, and J. P. Isacch. 1996. Abundancia y relaciones con el hábitat de aves y mamíferos en pastizales de Paspalum quadrifarium (paja colorada) manejados con fuego (Provincia de Buenos Aires, Argentina). Interciencia 21:228-237.

Congalton, R. G. 1991. A review of assessing the accuracy of classifications of remote sensed data. Remote Sensing and Environment 37:35-46.

Congalton, R. G. 2001. Accuracy assessment and validation of remotely sensed and other spatial information. International Journal of Wildland Fire 10: 321-328.

DarWIN, C. 1839. Journal of researches into the natural history and geology of the countries visited during the voyage of HMS Beagle round the world under the command of Capt. Fitzroy. London, UK: Henry Colburn Publisher.

Demaría, M. R., W. J. McShea, K. Koy, and N. 0. Maceira. 2004. Pampas deer conservation with respect to habitat loss and protected area considerations in San Luis, Argentina. Biological Conservation 115:121-130.

Egbert, S. L., R. Y. Lee, K. P. Price, R. Boyce, and M. D. Nellis. 1997. Mapping the Kansas grasslands: a multi-temporal approach. Gap Analysis Bulletin 6:12-13.

Everitt, J. H., A. J. Richardson, and C. L. Wiegand. 1981. Inventory of semi-arid rangelands in south Texas with Landsat data. In: Proceedings of the Symposium on Machine Processing Remotely Sensed Data. West Lafayette, IN: Laboratory for Applications of Remote Sensing, Purdue University. p 404-415.

FrenguelLI, J. 1950. Rasgos generales de la morfología y geología de la Provincia de Buenos Aires. La Plata, Argentina: LEMIT. Series II. No. 33.

Guerschman, J. P., J. M. Paruelo, C. M. Di Bella, M. C. Giallorenzi, and F. Pacin. 2003. Land cover classification in the Argentine Pampas using multi-temporal Landsat TM data. International Journal of Remote Sensing 24:3381-3402.

Guo, X., K. P. Price, And J. M. Stiles. 2000. Biophysical and spectral characteristics of cool and warm season grasslands under three management practices in Eastern Kansas Convection. Washington, DC: American Society of Photogrammetric Engineering and Remote Sensing (ASPRS).

Juan, V. F., L. Monterroso, M. B. Sacido, and M. A. Cauhépé. 2000. Postburning legume seedling in the Flooding Pampas, Argentina. Journal of Range Management 53:300-304.

Krapovickas, S., AND A. S. DI Giacomo. 1998. Conservation of pampas and campos grasslands in Argentina. Parks 8:47-53

LATERRA, P. 1997. Post-burn recovery in the Flooding Pampa: impact of an invasive legume. Journal of Range Management 50:274-277.

Laterra, P., 0. R. Vignolio, L. G. Hidalgo, 0. N. Fernández, M. A. Cauhépé, and N. 0. MacelRA. 1998. Dinámica de pajonales de paja colorada (Paspalum spp.) manejados con fuego y pastoreo en la Pampa Deprimida Argentina Ecotrópicos 11:41-149.
Laterra, P., 0. R. Vignolio, M. P. Linares, A. Giaquinta, and N. Maceira. 2003. Cumulative effects of fire on a tussock pampa grassland. Journal of Vegetation Science 14:43-54.

Martínez, G. A., J. Martínez Arca, Q. H. J. Gwyn, and M. V. Bernasconi. 2001. Combined use of Radarsat- 1 and Landsat TM data for geomorphological applications in lowlands of Buenos Aires Province, Argentina. Canadian Journal of Remote Sensing 27:638-642.

Mather, P. 1999. Computer processing of remotely sensed image. New York, NY: John Wiley and Sons, Inc.

Monserud, R. A. 1990. Methods for comparing global vegetation maps. Laxenburg, Austria: Institute for Applied Systems Analysis (IASA). WP-90-40.

Paruelo, J. M., M. Osterheld, C. M. Di Bella, M. Cahuépé, M. Rebella, C. M. Arzadum, AND J. LAfontaine. 1998. Calibración de la relación NDVI—productividad primaria para el pastizal de la pampa inundable. Proceedings of the 14th Jornadas Argentinas de Teleobservación; June 17-19, 1998; CONAE, Buenos Aires, Argentina.

Paruelo, J. M., M. F. Garbuslky, J. P. Guerschman, and M. O. Osterheld. 1999. Caracterización regional de los recursos forrajeros de las zonas templadas de Argentina mediante imágenes satelitarias. Revista Argentina de Producción Animal 19:125-131.

Paruelo, J. M., E. G. Jobbágy, and 0. E. Sala. 2001. Current distribution of ecosystem functional types in temperate South America. Ecosystems 4:683-698.

Perelman, S. B., R. J. C. León, and M. Oesterheld. 2001. Cross-scale vegetation patterns of Flooding Pampa grasslands. Journal of Ecology 89:562-577.

Perelman, S. B, S. E. Burkart, and R. J. C. León. 2003. The role of a native tussock grass (Paspalum quadrifarium Lam.) in structuring plant communities in the Flooding Pampa grasslands, Argentina. Biodiversity and Conservation 12: 225-238.

Price, K. P., X. Guo, And J. M. Stiles. 1999. Discriminant analysis of Landsat TM multi-temporal data for six grassland management practices in eastern Kansas. In: Proceedings of the ASPRS; May 17-21, 1999; Portland, OR: American Society of Photogrammetric and Remote Sensing. p 498-508.

Quarin, C. L., and E. P. Lombardo. 1986. Niveles de ploidía y distribución geográfica de Paspalum quadrifarium (Gramínea). Mendeliana 7:101-107.

Rosenfield, J. H., and K. Fitzpatrick-lins. 1986. A coefficient of agreement as a measure of thematic classification accuracy. Photogrammetric Engineering and Remote Sensing 52:223-227.

Soriano, A. 1991. Río de la Plata Grasslands. In: R. T. Coupland [ed.]. Natural grasslands. Amsterdam, The Netherlands: Elsevier. p 367-407.

Tucker, J. C., J. R. G. Townshend, and T. E. Goff. 1985. African land-cover classification using satellite data. Science 227:369-375.

TuelleR, P. T. 1989. Remote sensing technology for rangeland management applications. Journal of Range Management 42:442-453.

Vervoorst, F. B. 1967. Las comunidades vegetales de la Depresión del Salado (Provincia de Buenos Aires). La vegetación de la República Argentina. Buenos Aires, Argentina: Instituto Nacional de Tecnología Agropecuaria. Serie fitogeográfica 7. $262 \mathrm{p}$.

Vignolio, 0. R., P. Laterra, 0. N. Fernández, M. P. Linares, N. 0. Maceira, and A. GIAQUINTA. 2003. Effects of fire frequency on survival, growth and fecundity of Paspalum quadrifarium (Lam.) in a grassland of the Flooding Pampa (Argentina). Austral Ecology 28:263-270.

Zar, J. H. 1984. Biostatistical analysis. Englewood Cliffs, NJ: Prentice Hall, Inc. $718 \mathrm{p}$. 